\title{
Banking Sector Reforms and the Performance of the Nigerian Industrial Sector
}

\author{
Bernhard O. ISHIORO
}

Department of Economics, Delta State University, Abraka

\begin{abstract}
The Nigerian economy has been experiencing a lot of reforms in the banking subsector. Despite these reforms that ought to have enhanced the performance of the industrial sector of the economy, the weak performance of the industrial sector has survived unscathed and prolonged. Therefore, the major interest of this paper is to investigate the long and short-run relationships existing between banking sector reforms and the performance of the industrial sector in Nigeria. The study begins with a review of the banking sector reforms and the link to the industrial sector performance. Time series data from 1982-2015 are used to empirically assess the long-run relationship between banking sector reforms-targeted variables and the Nigerian industrial sector. The Modified PANTULA Principle was adopted in the selection of the most suitable variant of the Johansen Cointegration technique and found that model three was only suitable in the determination of the long-run relationship between commercial banks credit to the industrial sector and industrial production, and not manufacturing capacity utilisation.Summary of the variants of the Johansen cointegration equations were provided to facilitate a robust discussion of the long-run relationship between the indicators of banking sector reforms and industrial sector performance. A modified variant of causality test was adopted in the investigation of the direction of causality that exist between the reforms variables and industrial sector performance indicators. Various lag selection techniques were applied and found the Final Prediction Error(FPE) as most suitable. The Vector Auto Regression (VAR) impulse response and variance decomposition were applied to determine the effects of the reforms shocks on the industrial sector performance variables. The results shows amongst other that in the era reforms, the shocks from the banking sector credit to the industrial sector is higher than other reforms indices. This makes credit to the industrial sector a potent force in the enhancement of industrial sector performance in Nigeria. Therefore, banking sector reforms should be designed to enhance the consistent flow of credit to the industrial sector of the economy. Structural breaks were also applied to see the effects of the changes in reforms on the performance of the industrial sector.
\end{abstract}

Keywords: Banking Sector Reforms and the Performance of the Nigerian Industrial Sector

JEL Classification: C32,E43,E51,G21 